\title{
News in Cellular Allergology: A Review of the Human Mast Cell and Basophil Granulocyte Literature from January 2013 to May 2015
}

\author{
Hans Jürgen Hoffmann \\ Department of Respiratory Diseases and Allergy, Institute for Clinical Medicine, Aarhus University and Hospital, \\ Aarhus, Denmark
}

\section{Key Words}

Allergy · Basophils · Mast cell degranulation · Mast cell protease $\cdot$ Mast cells $\cdot$ Maturation

\begin{abstract}
Mast cell activation releases the mediators associated with type I allergy. As such, the study of mast cell activation is critical for understanding the allergic reaction, and for developing methods to control it. Importantly, another ligand receptor pair (compound 48/80 and MRGPRX2) that activates mast cells in addition to allergen-lgE-FcERI has been identified. As mast cells mature in tissue from hematopoietic stem cells, their physiology and pathophysiology is difficult to study. Mast cell lines and mast cells cultured from stem cells are often studied instead of tissue mast cells. There has been some progress in the description of the mechanism of the activation of mast cells, substances limiting mast cell activation and in the catalogue of proteases that mast cells express. Basophil granulocytes express FcعRl, bind IgE and respond to allergen crosslinking in a very similar fashion to mast cells. In the recent literature, basophils were mistakenly described as antigen-presenting cells; this has convincingly been disputed in a number of subsequent publications. Their function in physiology and pathophysiology is not known, but they are frequently used to docu-
\end{abstract}

ment allergic sensitisation in the basophil activation test. Significant progress has been made in documenting the relevance of basophil activation as a second-line test in allergy diagnosis. Basophil reactivity and sensitivity may reflect symptom severity and allergen threshold, and are used to document and monitor allergy. The physiology and pathophysiology of allergic effector cells remain an important area of research.

(c) 2016 S. Karger AG, Basel

\section{An Update on the Role of Mast Cells in Allergic Response}

Mast cells may have developed 500 million years ago, as man shares cells secreting heparin and histamine in response to compound $48 / 80$ with the urochordate sea squid Styela plicata [1]. In a recent transcriptome analysis mast cells were shown to share many features with nonleukocyte cells [2], which makes them rather unique. MRGPRX2, the receptor for compound $48 / 80$, was among the novel markers of mast cells not expressed by blood basophils [3]. Mast cells derive from hematopoietic stem cells that mature in tissue. For this reason they are difficult to study; both immortalised mast cell lines and primary cultures of mast cells derived from stem cells are

\section{KARGER 125}

(c) 2016 S. Karger AG, Base

$1018-2438 / 16 / 1684-0253 \$ 39.50 / 0$

E-Mail karger@karger.com

www.karger.com/iaa
Correspondence to: Prof. Dr. Hans-Jürgen Hoffmann

Department of Respiratory Diseases and Allergy, Institute for Clinical Medicine Aarhus University and Hospital

Nørrebrogade 44, DK-8000 Aarhus C (Denmark)

E-Mail hjh@clin.au.dk 
used for the study of the function of mast cells in vitro. In a comparison of primary human mast cell culture protocols [4], mast cells derived from CD133+ stem cells from peripheral blood [5] were more versatile in secreting both histamine and cytokines, and hence the most mature. The generation of arachidonic acid metabolites is a major cause of asthma symptoms [6] and mast cells cultured with low-density lipoprotein as a lipid source depend on both adipose triglyceride lipase or cytosolic phospholipase A2 for generation of these fatty acids [7]. The distribution of long- and short-chain polyunsaturated fatty acids in culture medium modified the inflammatory profile (reactive oxygen species, IL4 and IL13 generation) of mast cell lines LAD2 and HMC.1 [8]. As an alternative to primary mast cells, the human mast cell line LAD2 has been available since 2003; it has been used extensively to study receptor expression, cell signalling and degranulation [9].

\section{Mast Cell Priming and Activation by Exogenous Substances}

IL33 is a survival factor for mast cells [10] that does not induce degranulation of mast cells or basophils, but is released during activation of these cells [11]. TSLP (thymic stromal lymphopoietin) and IL33 synergise with IgE to enhance Cys-LT, but not PGD2 synthesis in human cord blood-derived mast cells [12]. Mast cell tryptase and chymase mature IL33 to a more potent form lacking the first 95-108 amino acids, which activates ILC2 30 -fold more than the native IL33 does [13]. An acute response to IL33 results in neutrophil recruitment by human mast cells [14], but after $72 \mathrm{~h} \mathrm{IL33}$ induces a hyporesponsive phenotype in murine and human mast cells through MyD88mediated downregulation of phospholipase $\mathrm{C} 1$ and $\mathrm{Hck}$ [15].

Mast cells recognise an invading virus through intracellular virus sensors $[16,17]$. Human influenza A virus and respiratory syncytial virus infect and activate mast cells, but do not amplify well in them $[18,19]$. Pretreatment with TLR2 agonists inhibits IgE-mediated activation of LAD2, whereas simultaneous activation through TLR2 and IgE synergises IL8 release [20]. Costimulation of peripheral blood-derived mast cells through IgE and TLR4 or TLR6 induces the production of IL13 [21].

In addition to IgE, basic secretagogues including compound 48/80, which also activates test cells in invertebrates [1], can activate mast cells through the receptor
MRGPRX2 [3]. This receptor is the target of a number of small molecules like the neuromuscular blocking agents atracurium and rocuronium, associated with anaphylactiod and pseudo-allergic reactions, and may be the receptor-mediating response in some drug allergies where it can be difficult to document drug-specific IgE.

The antimicrobial peptide Api88 from honeybee hemolymph induced mast cell activation [22]. Pleurocidin, a fish cationic antimicrobial peptide, activates mast cells to secrete CCL2 and CCL4 [23]. The human cathelithicin LL-37 activates degranulation and cytokine secretion, but not the synthesis of arachidonic acid metabolites [24].

The tryptophan metabolite kynurenine binds the aryl hydrocarbon receptor on mast cells to enhance degranulation [25]. Similarly, the $\beta$-blocker metoprolol in combination with either the ACE inhibitor ramipril or bradykinin increased the sensitivity of mast cells [26]. This mast cell priming was particularly effective when the FceRI engagement was suboptimal, as is often the case in vivo. Release of zinc from LAD2 cells was induced by FceRI crosslinking but partially independent of degranulation [27].

The anti-allergic mast cell stabilisers lodoxamide and bufrolin target GPR35, similar to cromolyn and nedocromil sodium, are more promising drug candidates as they are several orders of magnitude more potent [28]. A number of other factors inhibiting mast cell activation are listed in table 1 .

\section{Signalling in Mast Cells through FcERI and Factors Mediating This Process}

The best-studied process mast cells are involved in is degranulation in response to IgE crosslinking by allergens. A number of other functions have been ascribed to mast cells on the basis of research done in mast cell-deficient mice with spontaneous mutation-deleting kit, which also affect a range of other genes and hence are not as specific as proposed [29]. The transcription factors PU.1 and GATA1 are involved in FceRIa transcription, and GATA2 modulates FceRIb transcription. Suppression of these transcription factors leads to decreased expression of FceRI and IgE-mediated degranulation [30]. The microRNA miR-142-3p enhances FceRI-mediated activation, and can be inhibited by overexpression of Dicer, an enzyme in the miRNA pathway [31].

Mast cells can form an antibody-dependent secretory synapse based on either IgG or IgE, in which degranulat- 
Table 1. Mast cell inhibitors

\begin{tabular}{llc}
\hline Substance & Effect & $\begin{array}{c}\text { Reference } \\
\text { No. }\end{array}$ \\
\hline Prostaglandin E & & 109 \\
Vitamin D3 & Binds the EP2 receptor & 110 \\
Allergin-1 & & 111 \\
Artesunate & Inhibits IgE-mediated activation & 112 \\
Cinnamon extract & Inhibits Syk phosphorylation & 113 \\
Benzodiazepine & & 114 \\
Piceatannol & Binds the adenosine A(2B) receptor & 115 \\
Homoisoflavone & & 116 \\
Tetramethyl-luteolin & Inhibits the Syk pathway & 117 \\
Caffeic acid phenethyl ester & & 118 \\
Clostridium difficile toxin B (TcdB) & Limiting phosphorylation of MAPK, c-Jun and NF- $\mathrm{B}$ \\
$\begin{array}{l}\text { Single-walled carbon nanotubes } \\
\text { Water-soluble C70 fullerenes }\end{array}$ & Inactivating Rho-family GTPases by glycosylation & 119 \\
$\quad$ & & 120 \\
\hline
\end{tabular}

ing substances are present at a high concentration [32]. IgE stabilises FceRI on mast cells, with varying FceRI concentration at a very high and varying sensitivity at a very low concentration of IgE [33]. Mast cell expression of FceRI and histamine release was optimal at $250 \mathrm{ng} / \mathrm{ml}$ of IgE in the medium. Synthesis of prostaglandin D2 was less affected by the IgE concentration [34]. Once the signal of allergen crosslinking FceRI reaches inside the cell, Syk stimulation has to override the phosphatase activity of SHP-1 and SHIP [35]. Cytoplasmic free FceRIb may function as a negative regulator of FceRI activation by sequestering lyn kinase [36]. A truncated form of FceRIb containing a calmodulin-binding domain may be involved in intracellular poising of mast cells for degranulation [37]. Mitochondrial STAT3 is induced by ERK1/2 to induce oxidative phosphorylation that precedes degranulation [38]. Inhibition of STAT3 signalling in mast cells leads to impaired FceRI-mediated proximal and distal signalling, as well as reduced degranulation [39].

\section{The Protease Expression Palette of Mast Cells}

Mast cell chymase has been proposed as a differentiation marker for connective tissue mast cells [40, 41]. However, given enough time, the gene for chymase is expressed by $100 \%$ of cultured mast cells $[42,43]$. Chymase may thus be a marker of mast cell age, rather than a differentiation marker. If this is true, the fraction of mast cells expressing chymase could be used as an indicator of the turnover of mast cells in that particular tissue.

The mucosa of patients with food allergy and gastrointestinal symptoms contains elevated levels of tryptase [44]. In addition to the lineage-specific expression of tryptase, human mast cells express granzyme $\mathrm{H}$ [45]. HMC-1 expresses metalloproteases of the A disintegrin and metalloproteinase with thrombospondin motifs (ADAMTS) family members 5, 6 and 9 [46].

\section{Progress in Research on the Function and Diagnostic Application of Human Blood Basophil Granulocytes}

Evidence for a role of basophils in allergic or other diseases has been scant - in part hampered by the large difference in immune biology and basophil function between man and mouse. Basophils share a number of features with mast cells, in particular they are circulating cells expressing functional FceRI that degranulate upon allergen crosslinking. A recent gene expression study found little relation between basophils and mast cells beyond this observation [2]. Whereas mast cells express genes shared with cells not primarily dedicated to immune function, blood basophils were typical myeloid immune cells. The ready availability of blood basophils has made them a choice ex vivo tool for elucidating the response to IgE crosslinking in the basophil activation test (BAT), which was the subject of a recent EAACI position paper [47]. 


\section{Factors Affecting Basophil Activation}

Both the nature of the allergen and the condition of blood basophils contribute to basophil activation. The heavily glycosylated allergen Hev b 2 may activate basophils through the carbohydrate moiety [48]. Ammonium persulfate oxidises human albumin to create an allergen that sensitised hairdressers' basophils responded to specifically in BAT [49]. Additional allergens identifiable by $\mathrm{BAT}$ are listed in table 2.

A major advantage of BAT is that recombinant allergens (that have to undergo expensive and extensive GMP for use in man) can be used as it occurs ex vivo. A recurrent concern is the presence of LPS in such preparations. Only an unnaturally high LPS concentration (>200 ng/ $\mathrm{ml}$ ) elevated CD63 upregulation and histamine release from allergen-stimulated basophils [50]. An LPS contamination $<50 \mathrm{ng} / \mathrm{ml}$ of allergen preparations may thus not influence the outcome of a BAT.

Aspirin enhances the phosphorylation of Syk to intensify the degranulation of basophils [51]. Escalating doses of sub-threshold allergen, however, induce anergy to FceRI-mediated activation in blood basophils [52]. Ingestion of the common dietary isoform of vitamin $\mathrm{E}, \gamma$ tocopherol, significantly decreased the CD63 and CD203c reactivity of basophils ex vivo of mite-allergic patients [53]. The ingestion of ligands of nicotinic acetylcholine receptors on basophils inhibited FceRI-mediated upregulation of CD203c [54].

\section{Progress in the Diagnosis and Monitoring of Allergy by Basophil Activation}

The provocation outcome of wheat-sensitised patients could be predicted with a combination of basophil sensitivity and s-IgE to wheat allergen [55]. Spontaneous CD203c expression on blood basophils and basophil reactivity correlate with the degree of tolerance among patients with cow's milk allergy [56]. Food-allergic patients sensitised to lipid transfer proteins could be sensitised to Cannabis sativa or Humulus, and were more than 10-fold more sensitised to cannabis extract [57]. The discovery of novel strong sensitising allergens suggests that the strongest primary sensitising allergens may yet to be discovered.

Purified natural and recombinant Pan b 1 at $0.5 \mu \mathrm{g} / \mathrm{ml}$ $(15 \mu \mathrm{M})$ activated basophils to a similar degree as $1 \mu \mathrm{g} / \mathrm{ml}$ of shrimp extract [58]. BAT with molecular allergen Ara h 2 is good at identifying true peanut-allergic Mediterra-
Table 2. Allergens characterised by BAT reactivity

\begin{tabular}{ll}
\hline Allergen & $\begin{array}{l}\text { Reference } \\
\text { No. }\end{array}$ \\
\hline Pholcodine & 122 \\
Iomeprol & 123 \\
Carboplatin & 124 \\
Piperacillin & 125 \\
L-asparaginase, treatment of paediatric leukaemia & 126 \\
Atracurium & 127 \\
Tick bite & 128 \\
a-Gal, cetuximab & 129 \\
Carminic acid & 130 \\
Iroko wood & 131 \\
Sesame (tahini sauce) & 132 \\
Pristinamycin & 133 \\
Formaldehyde & 134 \\
\hline
\end{tabular}

nean patients and distinguishing them from peach-allergic patients [59]. Ara h 2 and Ara h 6 may be allergologically redundant, and the native, purified allergens independently account for most peanut sensitisation of patients in Colorado [60].

The basophil sensitivity of peanut-allergic children was more reproducible than a double-blind, placebocontrolled food challenge [61], and severe peanut allergy was associated with a higher basophil sensitivity [62]. Change in basophil sensitivity can be assessed by measuring only a single allergen concentration [47]. In a twostep approach for diagnosing peanut allergy in the LEAP study, if only cases without clear first-line test results were investigated by BAT, the number of food challenges was reduced by $97 \%$ [63]. In the same study the reactivity of basophils correlated with symptom severity, whereas basophil sensitivity was associated with the allergen threshold at which allergic subjects responded [64]. Supporting this, symptom severity during failed oral food challenges correlated with basophil reactivity [65]. Basophil and mast cell activity in vivo depends on both the IgE affinity and concentration, and also on competing IgG4 to the same allergen [66]. Although hydrolysates of peanut flower appeared to reduce the molecular weight of allergens, the basophil reactivity of peanutallergic patients was not reduced by this treatment, suggesting that IgE epitopes were predominantly linear, and peptides containing $\operatorname{IgE}$ epitopes were resistant to degradation [67].

Light-sensitive allergens like fluoroquinolones should be prepared and tested under low light conditions as light 
reduces their allergenicity [68]. The predictive value, especially the negative predictive value of BAT, in the diagnosis of anaphylaxis to neuromuscular blocking agents is very good [69]. BAT should always only be considered after skin testing and s-IgE determination have been explored, unless there is evidence of the superiority of BAT. BAT is the only useful test during the diagnosis of rocuronium-related responses [69].

The identity of sensitising insects in patients with hymenoptera venom allergy but without s-IgE to venoms could be determined with BAT [70]. In a head-to-head comparison, CRD (component-resolved diagnosis) could not completely replace BAT in the diagnosis of Vespula vulgaris venom allergy in patients negative for other firstline tests [71]. Four of 149 patients could only be diagnosed by BAT. BAT with recombinant insect venom allergens improved specificity compared with s-IgE detection [72].

There was good concordance $(k=0.593)$ between ASST (autologous serum skin test) and BAT in the diagnosis of chronic urticaria [73]. The level of spontaneous CD203c expression on basophils of patients with chronic urticaria associates with disease intensity [74]. Naturally occurring auto-anti-IgE binding of both free and FceRIcomplexed IgE is found independently of the allergic status (and of the diagnosis of chronic urticaria?), and can both inhibit and accentuate basophil reactivity [75]. Patients with chronic urticaria may be sensitised to doublestranded DNA [76].

\section{Exploring the Mechanism of AIT with Basophil Activation}

Basophil sensitivity is reduced unspecifically during rush immunotherapy [77], in a process that can be reproduced ex vivo [52]. Basophil sensitivity reflected an increase in the protection afforded by subcutaneous immunotherapy (SCIT) with insect venom after 6 weeks and 1 year of treatment [78]. In grass pollen-allergic patients, basophil sensitivity to allergen decreases up to 500 -fold during updosing of subcutaneous allergen immunotherapy [79] and predicts the efficacy of SCIT. Similarly, basophil reactivity through CD203c at a submaximal allergen concentration was reduced by allergen immunotherapy [80]. Basophil sensitivity was significantly decreased by SCIT of grass pollen-allergic patients [81]. The effect of SLIT (sublingual immunotherapy) was markedly less than that of SCIT. Surprisingly, BAT reactivity increased during a course of SLIT [82].

News in Cellular Allergology

\section{Basophil Function during Treatment Modulating IgE or FceRI}

Therapy with anti-IgE reduces the activating signal and does not per se inhibit mast cell or basophil activation [83]. BAT reactivity was reduced by treatment with omalizumab [84]. Anti-IgE treatment disposes patients to be more sensitive to anti-IgE antibody, with more reactivity as well as greater sensitivity [85]. CD203c is a dynamic marker of basophil reactivity that is elevated in allergic patients before allergen stimulation, and is depressed during anti-IgE treatment in patients [86].

In addition to treating severe allergic asthma, anti-IgE is useful in the treatment of chronic urticaria [87, 88]. There are conflicting results regarding the effect of antiIgE on the concentration of blood basophils during treatment; it appears to increase (normalise) in adults suffering from chronic urticaria who present with a reduced number of blood basophils [83], but may be reduced in children treated for severe asthma [89].

DARPins selected to disrupt the IgE-FceRI interaction are more efficient at limiting IgE-mediated type I hypersensitivity response, and can prevent anaphylaxis in a humanised mouse model expressing human FceRI [90]. DARPins were $10^{2}$ - to $10^{4}$-fold more effective at disrupting the FceRI-IgE complex than omalizumab. The efficacy of IgE removal is not dependent on the affinity of the inhibitor but rather on its epitope specificity. A DARPin construct crosslinking FceRI and Fc $\gamma$ RII inhibited basophil activation [91]. This effect was increased by increasing the affinity of DARPin for Fc $\gamma$ RII [92].

\section{Progress in Elucidating the Biological Relevance of Basophils in Man}

TSLP activates basophils in bone marrow, blood and allergen-challenged lung [93]. Basophils are recruited to the site of allergic inflammation. This was confirmed by the detailed study of lung and blood basophils after allergen challenge in allergic patients, where accumulation of CD123+CD203c+ basophils in bronchoalveolar lavage corresponded with a decrease in the number of blood basophils [94]. The basophil sensitivity of patients with allergic rhinitis was more reproducible than the total nasal symptom score or nasal peak flow in challenge tests [95]. Local allergic rhinitis is a condition predominating in southern Europe. It can be diagnosed by BAT [96], which is both less time consuming and a more reproducible procedure than nasal provocation [95]. Blood basophils of

Int Arch Allergy Immunol 2015;168:253-262 
a-gal-sensitised individuals upregulated CD63 in vivo concomitant with the appearance of allergic symptoms after the ingestion of red meat [97].

Long-term (60 $\mathrm{min}$ ) exposure to sub-threshold doses of anti-FceRI antibody or allergen enhances basophil mediator release to the non-FceRI stimuli MCP-1, FMLP and leukotriene B4 [98]. Basophils express all TLRs, and TLR4 and TLR9 activation synergises with FceRIactivation to enhance IL4 and IL8 production, respectively [99]. Blood basophils constitutively express B cell activating factor BAFF, which is upregulated by TLR2 ligands and AMLP, but not by the TLR4 ligand LPS and not by allergens [100]. Purified basophils secrete TNF- $\alpha$ upon anti-IgE stimulation [101].

\section{Basophils Do Not Present Antigen to T Cells}

A major stir was caused by three reports in Nature about the antigen-presenting capacity of basophils. This has been refuted elegantly [102] and shown to be due to the confusion of basophils with plasmacytoid dendritic cells $[103,104]$. It is further refuted as basophils did not express the functional HLA class II molecules CD80 or CD86 [105, 106]. Basophils, in contrast to human mast cells [107], do not drive CD4 T cells toward an IL22-pro- ducing phenotype [105]. Basophils do not support Th17 $\mathrm{T}$ cell growth as they do not express costimulatory molecules required for interaction with $\mathrm{T}$ cells [108].

\section{Concluding Remarks}

Allergic effector cells are activated by allergen through FceRI - and respond in a remarkably similar way by releasing substances associated with the type I allergic response. Mast cells can also be activated through MRGPRX2, and the study of mast cell response in culture remains an important tool for understanding processes in allergy. Blood BAT is a useful second-line test for allergic sensitisation, and for assessing the effect of treatment that changes IgE to modulate allergy. During the diagnosis of allergy, blood basophils should be used in conditions that make them as sensitive a tool as possible. For the monitoring of allergic disease, blood basophils should reflect the in vivo situation as closely as possible. A number of factors that strengthen and limit basophil activity, and hence may affect basophil performance, have recently been described. Further research into allergic effector cells may result in drugs that interfere with the acute response, and in improved tools for diagnosing and monitoring allergy.

\section{References}

1 Cavalcante MC, Allodi S, Valente AP, Straus AH, Takahashi HK, Mourão PA, et al: Occurrence of heparin in the invertebrate Styela plicata (Tunicata) is restricted to cell layers facing the outside environment: an ancient role in defense? J Biol Chem 2000;275:3618936186.

2 Motakis E, Guhl S, Ishizu Y, Itoh M, Kawaji $\mathrm{H}$, de Hoon M, et al: Redefinition of the human mast cell transcriptome by deep-CAGE sequencing. Blood 2014;123:e58-e67.

3 McNeil BD, Pundir P, Meeker S, Han L, Undem BJ, Kulka M, et al: Identification of a mast-cell-specific receptor crucial for pseudo-allergic drug reactions. Nature 2015;519: 237-241.

4 Jensen BM, Frandsen PM, Raaby EM, Schiøtz PO, Skov PS, Poulsen LK: Molecular and stimulus-response profiles illustrate heterogeneity between peripheral and cord bloodderived human mast cells. J Leukoc Biol 2014; 95:893-901.

5 Andersen HB, Holm M, Hetland TE, Dahl C, Junker S, Schiøtz PO, et al: Comparison of short term in vitro cultured human mast cells from different progenitors - peripheral blood-derived progenitors generate highly mature and functional mast cells. J Immunol Methods 2008;336:166-174.

6 Beasley RC, Featherstone RL, Church MK, Rafferty P, Varley JG, Harris A, et al: Effect of a thromboxane receptor antagonist on PGD2and allergen-induced bronchoconstriction. J Appl Physiol 1989;66:1685-1693.

7 Dichlberger A, Schlager S, Maaninka K, Schneider WJ, Kovanen PT: Adipose triglyceride lipase regulates eicosanoid production in activated human mast cells. J Lipid Res 2014;55:2471-2478.

8 van den Elsen LWJ, Nusse Y, Balvers M, Redegeld FA, Knol EF, Garssen J, et al: n-3 longchain PUFA reduce allergy-related mediator release by human mast cells in vitro via inhibition of reactive oxygen species. Br J Nutr 2013; 109:1821-1831.

9 Kirshenbaum AS, Petrik A, Walsh R, Kirby TL, Vepa S, Wangsa D, et al: A ten-year retrospective analysis of the distribution, use and phenotypic characteristics of the LAD2 human mast cell line. Int Arch Allergy Immunol 2014;164:265-270.

10 Wang J-X, Kaieda S, Ameri S, Fishgal N, Dwyer D, Dellinger A, et al: IL-33/ST2 axis promotes mast cell survival via BCLXL. Proc Natl Acad Sci USA 2014;111:10281-10286.

11 Fux M, Pecaric-Petkovic T, Odermatt A, Hausmann OV, Lorentz A, Bischoff SC, et al: IL-33 is a mediator rather than a trigger of the acute allergic response in humans. Allergy 2014;69:216-222.

12 Lai Y, Altemeier WA, Vandree J, Piliponsky AM, Johnson B, Appel CL, et al: Increased density of intraepithelial mast cells in patients with exercise-induced bronchoconstriction regulated through epithelially derived thymic stromal lymphopoietin and IL-33. J Allergy Clin Immunol 2014;133:1448-1455.

13 Lefrançais E, Duval A, Mirey E, Roga S, Espinosa E, Cayrol C, et al: Central domain of IL-33 is cleaved by mast cell proteases for potent activation of group- 2 innate lymphoid cells. Proc Natl Acad Sci USA 2014;111:15502-15507. 
14 Enoksson M, Möller-Westerberg C, Wicher G, Fallon PG, Forsberg-Nilsson K, Lunderius-Andersson C, et al: Intraperitoneal influx of neutrophils in response to IL-33 is mast cell-dependent. Blood 2013;121:530-536.

15 Jung M-Y, Smrz D, Desai A, Bandara G, Ito T, Iwaki S, et al: IL-33 Induces a hyporesponsive phenotype in human and mouse mast cells. J Immunol 2013;190:531-538.

16 Lappalainen J, Rintahaka J, Kovanen PT, Matikainen S, Eklund KK: Intracellular RNA recognition pathway activates strong anti-viral response in human mast cells. Clin Exp Immunol 2013;172:121-128.

17 Tsutsui-Takeuchi $M$, Ushio $H$, Fukuda $M$, Yamada T, Niyonsaba F, Okumura K, et al: Roles of retinoic acid-inducible gene-I-like receptors (RLRs), Toll-like receptor (TLR) 3 and $2^{\prime}-5^{\prime}$ oligoadenylate synthetase as viral recognition receptors on human mast cells in response to viral infection. Immunol Res 2015;61:240-249.

18 Marcet CW, St Laurent CD, Moon TC, Singh $\mathrm{N}$, Befus AD: Limited replication of influenza A virus in human mast cells. Immunol Res 2013;56:32-43.

19 Al-Afif A, Alyazidi R, Oldford SA, Huang YY, King CA, Haidl ID, et al: Respiratory syncytial virus infection of primary human mast cells induces the selective production of type I interferons, CXCL10, and CCL4. J Allergy Clin Immunol 2015;136:1346-1354.

20 Yu Y, Yip KH, Tam IYS, Sam SW, Ng CW, Zhang W, et al: Differential effects of the Tolllike receptor 2 agonists, PGN and Pam3CSK4 on anti-IgE induced human mast cell activation. PLoS One 2014;9:e112989.

21 Suurmond J, Dorjée AL, Knol EF, Huizinga TWJ, Toes REM: Differential TLR-induced cytokine production by human mast cells is amplified by Fc囚RI triggering. Clin Exp Allergy 2015;45:788-796.

22 Keitel U, Schilling E, Knappe D, Al-Mekhlafi M, Petersen F, Hoffmann R, et al: Effect of antimicrobial peptides from Apis mellifera hemolymph and its optimized version Api88 on biological activities of human monocytes and mast cells. Innate Immun 2013;19:355367.

23 Pundir P, Catalli A, Leggiadro C, Douglas SE, Kulka M: Pleurocidin, a novel antimicrobial peptide, induces human mast cell activation through the FPRL1 receptor. Mucosal Immunol 2014;7:177-187.

24 Bąbolewska E, Brzezińska-Błaszczyk E: Human-derived cathelicidin LL-37 directly activates mast cells to proinflammatory mediator synthesis and migratory response. Cell Immunol 2015;293:67-73.

25 Kawasaki H, Chang H-W, Tseng H-C, Hsu S-C, Yang S-J, Hung C-H, et al: A tryptophan metabolite, kynurenine, promotes mast cell activation through aryl hydrocarbon receptor. Allergy 2014;69:445-452.

26 Nassiri M, Babina M, Dölle S, Edenharter G, Ruëff F, Worm M: Ramipril and metoprolol intake aggravate human and murine anaphy- laxis: evidence for direct mast cell priming. J Allergy Clin Immunol 2015;135:491-499.

27 Nakashima-Kaneda K, Matsuda A, Mizuguchi H, Sasaki-Sakamoto T, Saito H, Ra C, et al: Regulation of IgE-dependent zinc release from human mast cells. Int Arch Allergy Immunol 2013;161(suppl 2):44-51.

28 MacKenzie AE, Caltabiano G, Kent TC, Jenkins L, McCallum JE, Hudson BD, et al: The antiallergic mast cell stabilizers lodoxamide and bufrolin as the first high and equipotent agonists of human and rat GPR35. Mol Pharmacol 2014;85:91-104.

29 Rodewald H-R, Feyerabend TB: Widespread immunological functions of mast cells: fact or fiction? Immunity 2012;37:13-24.

30 Inage E, Kasakura K, Yashiro T, Suzuki R, Baba Y, Nakano N, et al: Critical roles for PU.1, GATA1, and GATA2 in the expression of human FceRI on mast cells: PU.1 and GATA1 transactivate FCER1A, and GATA2 transactivates FCER1A and MS4A2. J Immunol 2014; 192:3936-3946.

31 Yamada Y, Kosaka K, Miyazawa T, KurataMiura K, Yoshida T: miR-142-3p enhances FceRI-mediated degranulation in mast cells. Biochem Biophys Res Commun 2014;443: 980-986.

32 Joulia R, Gaudenzio N, Rodrigues M, Lopez J, Blanchard N, Valitutti S, et al: Mast cells form antibody-dependent degranulatory synapse for dedicated secretion and defence. Nat Commun 2015;6:6174.

33 Krohn IK, Lund G, Frandsen PM, Schiøtz PO, Dahl R, Hoffmann HJ: Mast cell FceRI density and function dissociate from dependence on soluble IgE concentration at very low and very high IgE concentrations. J Asthma 2013; 50:117-121

34 Frandsen PM, Krohn IJMK, Hoffmann HJ, Schiøtz PO: The influence of IgE on cultured human mast cells. Allergy Asthma Immunol Res 2013;5:409-414

35 Mahajan A, Barua D, Cutler P, Lidke DS, Espinoza FA, Pehlke C, et al: Optimal aggregation of FceRI with a structurally defined trivalent ligand overrides negative regulation driven by phosphatases. ACS Chem Biol 2014;9: 1508-1519.

36 Okayama Y, Matsuda A, Kashiwakura J-I, Sasaki-Sakamoto T, Nunomura S, Shimokawa $\mathrm{T}$, et al: Highly expressed cytoplasmic FceRI $\beta$ in human mast cells functions as a negative regulator of the $\mathrm{FcR} \gamma$-mediated cell activation signal. Clin Exp Allergy 2014;44:238-249.

37 Cruse G, Beaven MA, Ashmole I, Bradding P, Gilfillan AM, Metcalfe DD: A truncated splicevariant of the FceRI $\beta$ receptor subunit is critical for microtubule formation and degranulation in mast cells. Immunity 2013;38:906-917.

38 Erlich TH, Yagil Z, Kay G, Peretz A, Migalovich-Sheikhet H, Tshori S, et al: Mitochondrial STAT3 plays a major role in IgE-antigen-mediated mast cell exocytosis. J Allergy Clin Immunol 2014;134:460-469.

39 Siegel AM, Stone KD, Cruse G, Lawrence MG, Olivera A, Jung M, et al: Diminished al- lergic disease in patients with STAT3 mutations reveals a role for STAT3 signaling in mast cell degranulation. J Allergy Clin Immunol 2013;132:1388-1396.

40 Craig SS, Schwartz LB: Tryptase and chymase, markers of distinct types of human mast cells. Immunol Res 1989;8:130-148.

41 Irani AM, Schwartz LB: Human mast cell heterogeneity. Allergy Proc 1994;15:303-308.

42 Kinoshita T, Sawai N, Hidaka E, Yamashita T, Koike K: Interleukin-6 directly modulates stem cell factor-dependent development of human mast cells derived from $\mathrm{CD} 34^{+}$cord blood cells. Blood 1999;94:496-508.

43 Maaninka K, Lappalainen J, Kovanen PT: Human mast cells arise from a common circulating progenitor. J Allergy Clin Immunol 2013; 132:463-469.e3.

44 Hagel AF, deRossi T, Zopf Y, Konturek P, Dauth W, Kressel J, et al: Mast cell tryptase levels in gut mucosa in patients with gastrointestinal symptoms caused by food allergy. Int Arch Allergy Immunol 2013;160:350-355.

45 Rönnberg E, Calounova G, Sutton VR, Trapani JA, Rollman O, Hagforsen E, et al: Granzyme $\mathrm{H}$ is a novel protease expressed by human mast cells. Int Arch Allergy Immunol 2014;165:68-74.

46 García-Faroldi G, Rönnberg E, Orro A, Calounova $G$, Guss B, Lundequist A, et al: ADAMTS: novel proteases expressed by activated mast cells. Biol Chem 2013;394:291-305.

47 Hoffmann HJ, Santos AF, Mayorga C, Nopp A, Eberlein B, Ferrer M, et al: The clinical utility of basophil activation testing in diagnosis and monitoring of allergic disease. Allergy 2015;70:1393-1405.

48 Rodríguez-Romero A, Hernández-Santoyo A, Fuentes-Silva D, Palomares LA, MuñozCruz S, Yépez-Mulia L, et al: Structural analysis of the endogenous glycoallergen $\mathrm{Hev}$ b 2 (endo- $\beta$-1,3-glucanase) from Hevea brasiliensis and its recognition by human basophils. Acta Crystallogr D Biol Crystallogr 2014;70: 329-341.

49 Pignatti P, Frossi B, Pala G, Negri S, Oman H Perfetti L, et al: Oxidative activity of ammonium persulfate salt on mast cells and basophils: implication in hairdressers' asthma. Int Arch Allergy Immunol 2013;160:409-419.

50 Gyimesi E, Gönczi F, Szilasi M, Pál G, Baráth S, Sipka S: The effects of various doses of bacterial lipopolysaccharide on the expression of CD63 and the release of histamine by basophils of atopic and non-atopic patients. Inflamm Res 2013;62:213-218.

51 Matsuo H, Yokooji T, Morita H, Ooi M, Urata K, Ishii K, et al: Aspirin augments IgE-mediated histamine release from human peripheral basophils via Syk kinase activation. Allergol Int 2013;62:503-511.

52 Witting Christensen SK, Kortekaas Krohn I, Thuraiaiyah J, Skjold T, Schmid JM, Hoffmann HJH: Sequential allergen desensitization of basophils is non-specific and may involve p38 MAPK. Allergy 2014;69:13431349. 
53 Mills K, Lay J, Wu W, Robinette C, Kesic MJ, Dreskin SC, et al: Vitamin E, $\gamma$-tocopherol, diminishes ex vivo basophil response to dust mite allergen. Allergy 2014;69:541-544.

54 Watson BM, Oliveria JP, Nusca GM, Smith SG, Beaudin S, Dua B, et al: Inhibition of allergen-induced basophil activation by ASM024, a nicotinic receptor ligand. Int Arch Allergy Immunol 2014; 165:255-264.

55 Nilsson N, Nilsson C, Hedlin G, Johansson SGO, Borres MP, Nopp A: Combining analyses of basophil allergen threshold sensitivity, CD-sens, and IgE antibodies to hydrolyzed wheat, $\omega-5$ gliadin and timothy grass enhances the prediction of wheat challenge outcome. Int Arch Allergy Immunol 2013; 162:50-57.

56 Ford LS, Bloom KA, Nowak-Węgrzyn AH, Shreffler WG, Masilamani M, Sampson HA: Basophil reactivity, wheal size, and immunoglobulin levels distinguish degrees of cow's milk tolerance. J Allergy Clin Immunol 2013; 131:180-186.e1-e3.

57 Ebo DG, Swerts S, Sabato V, Hagendorens MM, Bridts CH, Jorens PG, et al: New food allergies in a European non-Mediterranean region: is Cannabis sativa to blame? Int Arch Allergy Immunol 2013;161:220-228.

58 Myrset HR, Fæste CK, Kristiansen PE, Dooper MMBW: Mapping of the immunodominant regions of shrimp tropomyosin Pan b 1 by human IgE-binding and IgE receptor crosslinking studies. Int Arch Allergy Immunol 2013;162:25-38.

59 Mayorga C, Gomez F, Aranda A, Koppelman SJ, Diaz-Perales A, Blanca-López N, et al: Basophil response to peanut allergens in Mediterranean peanut-allergic patients. Allergy 2014;69:964-968.

60 Chen X, Wang Q, El-Mezayen R, Zhuang Y, Dreskin SC: Ara h 2 and Ara h 6 have similar allergenic activity and are substantially redundant. Int Arch Allergy Immunol 2013; 160:251-258

61 Glaumann S, Nopp A, Johansson SGO, Borres MP, Nilsson C: Oral peanut challenge identifies an allergy but the peanut allergen threshold sensitivity is not reproducible. PLoS One 2013;8:e53465.

62 Homšak M, Silar M, Berce V, Tomazin M, Skerbinjek-Kavalar M, Celesnik N, et al: The relevance of basophil allergen sensitivity testing to distinguish between severe and mild peanut-allergic children. Int Arch Allergy Immunol 2013;162:310-317.

63 Santos AF, Douiri A, Bécares N, Wu S-Y, Stephens A, Radulovic S, et al: Basophil activation test discriminates between allergy and tolerance in peanut-sensitized children. J Allergy Clin Immunol 2014;134:645-652.

64 Santos AF, Du Toit G, Douiri A, Radulovic S, Stephens A, Turcanu V, et al: Distinct parameters of the basophil activation test reflect the severity and threshold of allergic reactions to peanut. J Allergy Clin Immunol 2015; 135: 179-186.
65 Song Y, Wang J, Leung N, Wang LX, Lisann $\mathrm{L}$, Sicherer SH, et al: Correlations between basophil activation, allergen-specific IgE with outcome and severity of oral food challenges. Ann Allergy Asthma Immunol 2015;114: 319-326.

66 Santos AF, James LK, Bahnson HT, Shamji $\mathrm{MH}$, Couto-Francisco NC, Islam S, et al: IgG4 inhibits peanut-induced basophil and mast cell activation in peanut-tolerant children sensitized to peanut major allergens. J Allergy Clin Immunol 2015;135:1249-1256.

67 Shi X, Guo R, White BL, Yancey A, Sanders $\mathrm{TH}$, Davis JP, et al: Allergenic properties of enzymatically hydrolyzed peanut flour extracts. Int Arch Allergy Immunol 2013;162: 123-130.

68 Mayorga C, Andreu I, Aranda A, Doña I, Montañez MI, Blanca-Lopez N, et al: Fluoroquinolone photodegradation influences specific basophil activation. Int Arch Allergy Immunol 2013;160:377-382.

69 Leysen J, Uyttebroek A, Sabato V, Bridts $\mathrm{CH}$, De Clerck LS, Ebo DG: Predictive value of allergy tests for neuromuscular blocking agents: tackling an unmet need. Clin Exp Allergy 2014;44:1069-1075.

70 Korošec P, Šilar M, Eržen R, Čelesnik N, Bajrović $\mathrm{N}$, Zidarn $\mathrm{M}$, et al: Clinical routine utility of basophil activation testing for diagnosis of hymenoptera-allergic patients with emphasis on individuals with negative venom-specific IgE antibodies. Int Arch Allergy Immunol 2013;161:363-368.

71 Ebo DG, Faber M, Sabato V, Leysen J, Bridts $\mathrm{CH}$, De Clerck LS: Component-resolved diagnosis of wasp (yellow jacket) venom allergy. Clin Exp Allergy 2013;43:255-261.

72 Balzer L, Pennino D, Blank S, Seismann H, Darsow U, Schnedler M, et al: Basophil activation test using recombinant allergens: highly specific diagnostic method complementing routine tests in wasp venom allergy. PLoS One 2014;9:e108619.

73 Irinyi B, Gyimesi E, Garaczi E, Bata ZS, Kemény L, Zeher M, et al: Extended diagnostic value of autologous serum skin test and basophil CD63 expression assay in chronic urticaria. Br J Dermatol 2013;168:656-658.

74 Ye Y-M, Yang E-M, Yoo H-S, Shin Y-S, Kim S-H, Park H-S: Increased level of basophil CD203c expression predicts severe chronic urticaria. J Korean Med Sci 2014;29:43-47.

75 Chan Y-C, Ramadani F, Santos AF, Pillai P, Ohm-Laursen L, Harper CE, et al: 'Auto-antiIgE': naturally occurring IgG anti-IgE antibodies may inhibit allergen-induced basophil activation. J Allergy Clin Immunol 2014;134: 1394-1401.e4.

76 Hatada Y, Kashiwakura J, Hayama K, Fujisawa D, Sasaki-Sakamoto T, Terui T, et al: Significantly high levels of anti-dsDNA immunoglobulin $\mathrm{E}$ in sera and the ability of dsDNA to induce the degranulation of basophils from chronic urticaria patients. Int Arch Allergy Immunol 2013;161(suppl 2):154-158.
77 Čelesnik N, Vesel T, Rijavec M, Šilar M, Eržen R, Košnik M, et al: Short-term venom immunotherapy induces desensitization of FceRImediated basophil response. Allergy 2012;67: 1594-1600.

78 Bidad K, Nawijn MC, van Oosterhout AJM, van der Heide S, Elberink JNGO: Basophil activation test in the diagnosis and monitoring of mastocytosis patients with wasp venom allergy. Cytometry B Clin Cytom 2014;86:183190

79 Schmid JM, Würtzen PA, Dahl R, Hoffmann $\mathrm{HJ}$ : Early improvement in basophil sensitivity predicts symptom relief with grass pollen immunotherapy. J Allergy Clin Immunol 2014; 134:741-744.e5.

80 Kepil Özdemir S, Sin BA, Güloğlu D, İkincioğulları A, Gençtürk Z, Misırlıgil Z: Short-term preseasonal immunotherapy: is early clinical efficacy related to the basophil response? Int Arch Allergy Immunol 2014; 164:237-245.

81 Aasbjerg K, Backer V, Lund G, Holm J, Nielsen NC, Holse M, et al: Immunological comparison of allergen immunotherapy tablet treatment and subcutaneous immunotherapy against grass allergy. Clin Exp Allergy 2014;44:417-428.

82 Garrido-Fernández S, García BE, Sanz ML, Echechipía S, Lizaso MT, Tabar AI: Are basophil activation and sulphidoleukotriene determination useful tests for monitoring patients with peach allergy receiving sublingual immunotherapy with a Pru $\mathrm{p}$ 3-enriched peach extract? J Investig Allergol Clin Immunol 2014;24:106-113.

83 Gericke J, Ohanyan T, Church MK, Maurer M, Metz M: Omalizumab may not inhibit mast cell and basophil activation in vitro. J Eur Acad Dermatol Venereol 2015;29:18321836.

84 Pereira Santos MC, Campos Melo A, Caetano A, Caiado J, Mendes A, Pereira Barbosa M, et al: Longitudinal study of the expression of FceRI and IgE on basophils and dendritic cells in association with basophil function in two patients with severe allergic asthma treated with Omalizumab. Eur Ann Allergy Clin Immunol 2015;47:38-40.

85 Macglashan DW, Saini SS: Omalizumab increases the intrinsic sensitivity of human basophils to IgE-mediated stimulation. J Allergy Clin Immunol 2013;132:906-911.e4.

86 Gernez Y, Tirouvanziam R, Yu G, Ghosn EEB, Reshamwala N, Nguyen T, et al: Basophil CD203c levels are increased at baseline and can be used to monitor omalizumab treatment in subjects with nut allergy. Int Arch Allergy Immunol 2011;154:318-327.

87 Maurer M, Rosén K, Hsieh H-J, Saini S, Grat$\tan$ C, Gimenéz-Arnau A, et al: Omalizumab for the treatment of chronic idiopathic or spontaneous urticaria. N Engl J Med 2013; 368:924-935. 
88 Metz M, Ohanyan T, Church MK, Maurer M: Omalizumab is an effective and rapidly acting therapy in difficult-to-treat chronic urticaria: a retrospective clinical analysis. J Dermatol Sci 2014;73:57-62.

89 Hill DA, Siracusa MC, Ruymann KR, Tait Wojno ED, Artis D, Spergel JM: Omalizumab therapy is associated with reduced circulating basophil populations in asthmatic children. Allergy 2014;69:674-677.

90 Eggel A, Baravalle G, Hobi G, Kim B, Buschor P, Forrer P, et al: Accelerated dissociation of IgE-FceRI complexes by disruptive inhibitors actively desensitizes allergic effector cells. J Allergy Clin Immunol 2014;133:1709-1719. e8.

91 Eggel A, Buschor P, Baumann MJ, Amstutz P, Stadler BM, Vogel M: Inhibition of ongoing allergic reactions using a novel anti-IgE DARPin-Fc fusion protein. Allergy 2011;66: 961-968.

92 Buschor P, Eggel A, Zellweger F, Stadler BM, Vogel M: Improved Fc $\gamma$ RIIb targeting functionally translates into enhanced inhibition of basophil activation. Int Arch Allergy Immunol 2014;163:206-214.

93 Salter BM, Oliveria JP, Nusca G, Smith SG, Watson RM, Comeau M, et al: Thymic stromal lymphopoietin activation of basophils in patients with allergic asthma is IL-3 dependent. J Allergy Clin Immunol 2015;136:16361644.

94 Dijkstra D, Hennig C, Hansen G, Biller H, Krug N, Hohlfeld JM: Identification and quantification of basophils in the airways of asthmatics following segmental allergen challenge. Cytometry A 2014;85:580-587.

95 Nopp A, Cardell LO, Johansson SGO: CDsens can be a reliable and easy-to-use complement in the diagnosis of allergic rhinitis. Int Arch Allergy Immunol 2013;161:87-90.

96 Gómez E, Campo P, Rondón C, Barrionuevo E, Blanca-López N, Torres MJ, et al: Role of the basophil activation test in the diagnosis of local allergic rhinitis. J Allergy Clin Immunol 2013;132:975-976.e5.

97 Commins SP, James HR, Stevens W, Pochan SL, Land MH, King C, et al: Delayed clinical and ex vivo response to mammalian meat in patients with IgE to galactose-alpha-1,3-galactose. J Allergy Clin Immunol 2014;134: 108-115.

98 Koketsu R, Yamaguchi M, Suzukawa M, Tanaka Y, Tashimo H, Arai H, et al: Pretreatment with low levels of FceRI-crosslinking stimulation enhances basophil mediator release. Int Arch Allergy Immunol 2013; 161(suppl 2):23-31.

99 Suurmond J, Stoop JN, Rivellese F, Bakker AM, Huizinga TWJ, Toes REM: Activation of human basophils by combined toll-like receptor- and FceRI-triggering can promote Th2 skewing of naive T helper cells. Eur J Immunol 2014;44:386-396.
100 Boita M, Heffler E, Pizzimenti S, Raie A, Saraci $\mathrm{E}$, Omedè $\mathrm{P}$, et al: Regulation of $\mathrm{B}$-cellactivating factor expression on the basophil membrane of allergic patients. Int Arch Allergy Immunol 2015;166:208-212.

101 Falkencrone S, Poulsen LK, Bindslev-Jensen C, Woetmann A, Odum N, Poulsen BC, et al: IgE-mediated basophil tumour necrosis factor alpha induces matrix metalloproteinase-9 from monocytes. Allergy 2013;68:614620.

102 Duriancik DM, Hoag KA: Mistaken identity: purified basophils likely contaminated with dendritic cells. Cytometry A 2014;85:570572.

103 Hammad H, Plantinga M, Deswarte K, Pouliot P, Willart MAM, Kool M, et al: Inflammatory dendritic cells - not basophils - are necessary and sufficient for induction of Th2 immunity to inhaled house dust mite allergen. J Exp Med 2010;207:2097-2111.

104 Rydnert F, Lundberg K, Greiff L, Lindstedt M: Circulating $\mathrm{CD} 1 \mathrm{c}^{+}$DCs are superior at activating Th2 responses upon $\mathrm{Phl} p$ stimulation compared with basophils and pDCs. Immunol Cell Biol 2014;92:557-560.

105 Sharma M, Kaveri SV, Bayry J: Human basophils lack the capacity to drive memory $\mathrm{CD}^{+} \mathrm{T}$ cells toward the IL-22 response. J Allergy Clin Immunol 2013;132:1457-1458.

106 Voskamp AL, Prickett SR, Mackay F, Rolland JM, O’Hehir RE: MHC class II expression in human basophils: induction and lack of functional significance. PLoS One 2013; 8:e81777.

107 Gaudenzio N, Laurent C, Valitutti S, Espinosa $\mathrm{E}$ : Human mast cells drive memory CD4+ T cells toward an inflammatory IL$22+$ phenotype. J Allergy Clin Immunol 2013;131:1400-1407.e11.

108 Sharma M, Stephen-Victor E, Poncet P, Kaveri SV, Bayry J: Basophils are inept at promoting human Th17 responses. Hum Immunol 2015;76:176-180

109 Säfholm J, Manson ML, Bood J, Delin I, Orre A-C, Bergman P, et al: Prostaglandin E2 inhibits mast cell-dependent bronchoconstriction in human small airways through the E prostanoid subtype 2 receptor. J Allergy Clin Immunol 2015;136:1232-1239. e1.

110 Yip K-H, Kolesnikoff N, Yu C, Hauschild N, Taing H, Biggs L, et al: Mechanisms of vitamin $\mathrm{D}_{3}$ metabolite repression of IgE-dependent mast cell activation. J Allergy Clin Immunol 2014;133:1356-1364.e14.

111 Nagai K, Tahara-Hanaoka S, Morishima Y, Tokunaga T, Imoto Y, Noguchi E, et al: Expression and function of Allergin-1 on human primary mast cells. PLoS One 2013;8: e76160.

112 Cheng C, Ng DSW, Chan TK, Guan SP, Ho WE, Koh AHM, et al: Anti-allergic action of anti-malarial drug artesunate in experimental mast cell-mediated anaphylactic models. Allergy 2013;68:195-203.
113 Hagenlocher Y, Bergheim I, Zacheja S, Schäffer M, Bischoff SC, Lorentz A: Cinnamon extract inhibits degranulation and de novo synthesis of inflammatory mediators in mast cells. Allergy 2013;68:490-497.

114 Hoffmann K, Xifró RA, Hartweg JL, Spitzlei $\mathrm{P}$, Meis K, Molderings GJ, et al: Inhibitory effects of benzodiazepines on the adenosine $A_{2 B}$ receptor mediated secretion of interleukin-8 in human mast cells. Eur J Pharmacol 2013;700:152-158.

115 Ko Y-J, Kim H-H, Kim E-J, Katakura Y, Lee W-S, Kim G-S, et al: Piceatannol inhibits mast cell-mediated allergic inflammation. Int J Mol Med 2013;31:951-958.

116 Lee YS, Hur S, Kim T-Y: Homoisoflavanone prevents mast cell activation and allergic responses by inhibition of Syk signaling pathway. Allergy 2014;69:453-462.

117 Weng Z, Patel AB, Panagiotidou S, Theoharides TC: The novel flavone tetramethoxyluteolin is a potent inhibitor of human mast cells. J Allergy Clin Immunol 2015; 135: 1044-1052.e5.

118 Cho MS, Park WS, Jung W-K, Qian Z-J, Lee D-S, Choi J-S, et al: Caffeic acid phenethyl ester promotes anti-inflammatory effects by inhibiting MAPK and NF- $\mathrm{kB}$ signaling in activated HMC-1 human mast cells. Pharm Biol 2014;52:926-932.

119 Balletta A, Lorenz D, Rummel A, Gerhard R, Bigalke $\mathrm{H}$, Wegner $\mathrm{F}$ : Clostridium difficile toxin $\mathrm{B}$ inhibits the secretory response of human mast cell line-1 (HMC-1) cells stimulated with high free- $\mathrm{Ca}^{2+}$ and GTP $\gamma \mathrm{S}$. Toxicology 2015;328:48-56.

120 Umemoto EY, Speck M, Shimoda LMN, Kahue K, Sung C, Stokes AJ, et al: Single-walled carbon nanotube exposure induces membrane rearrangement and suppression of receptor-mediated signalling pathways in model mast cells. Toxicol Lett 2014;229: 198-209.

121 Dellinger AL, Zhou Z, Kepley CL: A steroidmimicking nanomaterial that mediates inhibition of human lung mast cell responses. Nanomedicine 2014;10:1185-1193.

122 Leysen J, De Witte L, Sabato V, Faber M, Hagendorens M, Bridts C, et al: IgE-mediated allergy to pholcodine and cross-reactivity to neuromuscular blocking agents: lessons from flow cytometry. Cytometry B Clin Cytom 2013;84:65-70

123 Philipse E, Sabato V, Bridts C, De Clerck L, Ebo D: Basophil activation in the diagnosis of life-threatening hypersensitivity reaction to iodinated contrast media: a case report. Acta Clin Belg 2013;68:140-142.

124 Iwamoto T, Hirai H, Yamaguchi N, Kobayashi N, Sugimoto H, Tabata T, et al: Carboplatin-induced severe hypersensitivity reaction: role of IgE-dependent basophil activation and FceRI. Cancer Sci 2014;105: 1472-1479. 
125 Marraccini P, Digiesi G, Pignatti P, Bordini L, Previdi M: A clinical case of occupational allergy to piperacilline - a novel diagnostic method: basophil activation test (BAT) (in Italian). Med Lav 2013; 104:434-439.

126 Hino M, Shimojo N, Ochiai H, Inoue Y, Ando K, Chikaraishi K, et al: Expression of CD203c on basophils as a marker of immunoglobulin E-mediated L-asparaginase allergy. Leuk Lymphoma 2014;55:92-96.

127 Uyttebroek AP, Sabato V, Leysen J, Bridts $\mathrm{CH}$, De Clerck LS, Ebo DG: Flowcytometric diagnosis of atracurium-induced anaphylaxis. Allergy 2014;69:1324-1332.

128 Oltean BM, Ernst M, Renneker S, Bakheit MA, Seitzer U, Ahmed J: Whole antigenic lysates of Ixodes ricinus, but not Der-p2 allergen-like protein, are potent inducers of basophil activation in previously tick-exposed human hosts. Transbound Emerg Dis 2013;60(suppl 2):162-171.
129 Michel S, Scherer K, Heijnen IAFM, Bircher AJ: Skin prick test and basophil reactivity to cetuximab in patients with IgE to alpha-gal and allergy to red meat. Allergy 2014;69: 403-405.

130 Sugimoto N, Yamaguchi M, Tanaka Y, Nakase Y, Nagase H, Akiyama H, et al: The basophil activation test identified carminic acid as an allergen inducing anaphylaxis. J Allergy Clin Immunol Pract 2013;1:197199.

131 de las Marinas MD, Martorell C, Martorell A, Cerdá JC, Felix R, Guaita M, et al: Basophil activation test is a useful tool in occupational asthma due to iroko wood. J Investig Allergol Clin Immunol 2013;23:512-514.
132 Della-Torre E, Pignatti P, Yacoub M-R, Sabbadini M-G, Colombo G: In vivo tests with 'Tahini' sauce: new allergenic source to evaluate IgE-mediated hypersensitivity to sesame. Ann Allergy Asthma Immunol 2013; 110:209-210.

133 Viel S, Garnier L, Joly E, Rouzaire P, Nosbaum A, Pralong P, et al: The basophil activation test: a sensitive test in the diagnosis of allergic immediate hypersensitivity to pristinamycin. Int Arch Allergy Immunol 2015; 167:94-98.

134 Tanaka Y, Nakase Y, Yamaguchi M, Sugimoto N, Ohara K, Nagase H, et al: Allergy to formaldehyde: basophil histamine-release test is useful for diagnosis. Int Arch Allergy Immunol 2014;164:27-29. 